\title{
Pengaruh Pendekatan Metaphorical Thinking terhadap Kemampuan Berpikir Kritis dan Kecerdasan Emosional Siswa SMAN 4 Kayuagung
}

\author{
Tezha Kurnia Anggraeny ${ }^{1)}$, Rohana ${ }^{2)}$, Jayanti ${ }^{3)}$ \\ ${ }^{1223)}$ Program Studi Pendidikan Matematika, Fakultas Keguruan dan Ilmu Pendidikan, Universitas PGRI \\ Palembang, Jln. Jend. A. Yani Lr Gotong royong 9/10 Ulu, Palembang, Indonesia \\ email: ${ }^{1)}$ tesyaanggraeny@gmail.com, ${ }^{2)}$ rohana_pgri@yahoo.com, ${ }^{3)}$ jayanti2hr@gmail.com \\ (Received 17-01-2019, Reviewed 18-01-2019, Accepted 23-05-2019)
}

\begin{abstract}
This study aims to examine the effect of the Metaphorical Thinking Approach on students' critical thinking skills and emotional intelligence of SMA Negeri 4 Kayuagung. The design form in this study used an experimental method, namely Posttest-Only Control Design. The population in this study was class XI MIPA 4 of SMA Kayuagung High School, taken as many as two classes, namely class XI MIPA 1 as many as 30 students as the experimental class who received learning with Metaphorical Thinking Approach and class XI MIPA 3 as many as 33 students as a control class who received learning conventional. The technique of collecting data used tests and questionnaires. Data analysis used t-test (Independent Sample T-Test), by first testing normality and homogeneity. Based on the analysis of the data, the results obtained in this study indicated that: 1) there was an influence of the Metaphorical Thinking Approach on Students' critical Thinking Ability of SMA Negeri 4 Kayuagung, 2) there was the influence of the Metaphorical Thinking Approach on Students' Emotional Intelligence of SMA Negeri 4 Kayuagung.
\end{abstract}

Keywords: Metaphorical Thinking Approach, Critical Thinking Ability, Emotional Intelligence

\begin{abstract}
Abstrak
Penelitian ini bertujuan untuk mengkaji pengaruh Pendekatan Metaphorical Thinking terhadap kemampuan berpikir kritis dan kecerdasan emosional siswa SMA Negeri 4 Kayuagung. Desain penelitian ini menggunakan metode eksperimen yaitu Posttest-Only Control Design. Populasi dalam penelitian ini adalah kelas XI MIPA SMA Negeri 4 Kayuagung, diambil sampel sebanyak dua kelas yaitu kelas XI MIPA 1 sebanyak 30 siswa sebagai kelas eksperimen yang mendapat pembelajaran dengan Pendekatan Metaphorical Thinking dan kelas XI MIPA 3 sebanyak 33 siswa sebagai kelas kontrol yang mendapatkan pembelajaran konvensional. Teknik pengumpulan data menggunakan tes dan angket. Analisis data menggunakan uji t (Independent Sample T-Test), dengan terlebih dahulu menguji normalitas dan homogenitas. Berdasarkan analisis data tersebut, hasil yang diperoleh dalam penelitian ini menunjukkan bahwa: 1) ada pengaruh Pendekatan Metaphorical Thinking terhadap Kemampuan Berpikir Kritis Siswa SMA Negeri 4 Kayuagung, 2) ada pengaruh Pendekatan Metaphorical Thinking terhadap Kecerdasan Emosional Siswa SMA Negeri 4 Kayuagung.

Kata Kunci: Pendekatan Metaphorical Thinking, Kemampuan Berpikir Kritis, Kecerdasan Emosional
\end{abstract}




\section{PENDAHULUAN}

Tuntutan zaman yang semakin maju, memaksa seseorang untuk dapat bertahan menghadapi masalah yang lahir dan muncul seiring perkembangan zaman. Keterpaksaan tersebut mengakibatkan timbulnya kesadaran bahwa tiap individu harus memiliki kemampuan andalan untuk kehidupannya, yang pada akhirnya membawa mereka masuk ke dunia pendidikan. Pendidikan dapat diartikan sebagai suatu proses dalam rangka mempengaruhi peserta didik agar mampu menyesuaikan dan dengan demikian akan menimbulkan perubahan dalam dirinya yang memungkinkannya untuk berfungsi secara tepat dalam kehidupan masyarakat (Hamalik, 2017). Dari definisi di atas, maka dapat dikatakan bahwa pendidikan merupakan pondasi utama dalam perkembangan kemampuan peserta didik. Karena dengan pendidikanlah potensi yang dimiliki dapat dieksplore dan dikembangkan.

Pendidikan mencakup berbagai bidang yang saling terkait satu sama lainnya, salah satunya yaitu matematika. Matematika merupakan salah satu disiplin ilmu yang dapat meningkatkan kemampuan berpikir dan beragumentasi, memberikan konstribusi dalam penyelesaian masalah sehari-hari dan dalam dunia kerja, serta memberikan dukungan dalam pengembangan ilmu pengetahuan dan teknologi (Susanto, 2016). Oleh karena itu, matematika sebagai ilmu dasar yang berpotensi meningkatkan kemampuan berpikir peserta didik perlu dikuasai dengan baik. Potensi tersebut dapat terwujud bila pembelajaran matematika menekankan pada aspek peningkatan kemampuan berpikir tingkat tinggi yang mengharuskan siswa memanipulasi informasi dan ide-ide dalam cara tertentu yang memberi mereka pengertian dan pengetahuan baru. Kemampuan berpikir tingkat tinggi terdiri dari berbagai aspek, salah satunya yaitu kemampuan berpikir kritis. Sesuai dengan visi matematika yaitu agar peserta didik memiliki kemampuan matematik memadai, berpikir dan bersikap kritis, kreatif dan cermat, obyektif dan terbuka, menghargai keindahan matematika, serta rasa ingin tahu dan senang belajar matematika (Asnawati, K.D., \& Muhtarulloh, 2015). Maka dengan visi matematika di atas berpikir kritis merupakan salah satu kemampuan penting yang harus dimiliki dan dikuasai oleh peserta didik agar tujuan pembelajaran matematika dapat tercapai.

Meskipun kemampuan berpikir kritis ini terbilang kemampuan yang penting untuk dimiliki dan dikuasai peserta didik namun kenyataannya dalam dunia pendidikan Indonesia, kemampuan berpikir kritis siswa masih terbilang rendah. Hal ini dapat dilihat berdasarkan hasil penelitian TIMSS (Trends in International Mathematics and Science Study) pada tahun 2015, Indonesia berada pada peringkat ke-45 dari 50 negara peserta 
dengan skor 397 jauh di bawah standar skor rata-rata 600 (Puspendik, 2017). Hal ini menunjukkan bahwa kemampuan berpikir kritis peserta didik di Indonesia masih terbilang rendah dan perlu untuk ditingkatkan.

Berpikir kritis merupakan bentuk pikir yang perlu dikembangkan dalam rangkaian memecahkan masalah, merumuskan simpulan, mengumpulkan bebagai kemungkinan dan membuat keputusan ketika menggunakan semua keterampilan tersebut secara efektif dalam konteks dan tipe yang tepat (Susanto, 2016). Berdasarkan definisi di atas maka dapat disimpulkan bahwa berpikir kritis merupakan cara berpikir mendalam yang melibatkan pengetahuan, pemahaman, keterampilan, dan kemampuan siswa untuk dapat memutuskan apa yang harus dipercaya dan dilakukan. Selain kemampuan berpikir kritis, terdapat aspek psikologi yang memberikan kontribusi terhadap keberhasilan siswa dalam menerapkan kemampuan berpikir kritis dengan baik. Aspek psikologi tersebut adalah kecerdasan emosional peserta didik. Kecerdasan emosional adalah kemampuan siswa untuk mengenali emosi diri, mengelola emosi diri, memotivasi diri sendiri, mengenali emosi orang lain (empati), dan kemampuan untuk membina hubungan (kerja sama) dengan orang lain (Adeyanto, Kusmayadi, \& Riyadi, 2016). Peserta didik yang mempunyai tingkat kecerdasan emosional yang baik maka dia akan mampu bangkit kembali dengan cepat dari suatu kegagalan dalam meraih prestasi, memiliki keterampilan berinteraksi dengan orang lain, mampu mengatur emosi untuk mencapai tujuan, serta cakap dalam kepemimpinan.

Peneliti melakukan studi pendahuluan yang dilakukan di SMA Negeri 4 Kayuagung dengan materi program linear kepada 30 siswa yang digunakan untuk mengetahui kemampuan berpikir kritis siswa dengan beberapa indikator, yang pertama yaitu menginterpretasi atau memahami masalah yang ditunjukkan dengan menuliskan apa yang diketahui dan ditanyakan pada soal dengan tepat, kedua yaitu menganalisis atau mengidentifikasi hubungan yang ada ditunjukkan dengan membuat model matematika dengan tepat dan memberikan penjelasan, ketiga adalah mengevaluasi yaitu menggunakan strategi yang lengkap, tepat dan benar perhitungannya dalam menyelesaikan soal, dan indikator yang keempat adalah menginferensi yaitu membuat kesimpulan dengan tepat (Aunurrahman, 2016). Hasil dari studi pendahuluan yang dilakukan peneliti menunjukkan bahwa hanya sekitar 30\% atau 9 dari 30 siswa saja yang terlihat mempunyai kemampuan berpikir kritis sedangkan $70 \%$ atau 21 dari 30 siswa lainnya belum mempunyai kemampuan berpikir kritis. Hal ini terlihat dari jawaban siswa 
dimana dari empat indikatornya siswa tidak menuliskan interpretasinya yaitu menuliskan apa yang diketahui dan ditanya dari soal, pada langkah analisisnya siswa belum bisa menuliskan model matematika dengan benar, pada langkah penyelesaian pun beberapa siswa menggunakan strategi perhitungan yang tidak tepat dan tidak lengkap dan pada langkah penarikan kesimpulan kebanyakan siswa yang tidak menuliskan kesimpulan. Berdasarkan hasil studi pendahuluan tersebut terlihat jelas bahwa kemampuan berpikir kritis siswa kelas XI di SMA Negeri 4 Kayuagung sangat rendah karena jawaban siswa belum memenuhi indikator kemampaun berpikir kritis.

Peneliti juga melakukan wawancara kepada salah satu guru mata pelajaran matematika yang ada di SMA Negeri 4 Kayuagung untuk melihat kecerdasan emosional siswa yang diukur berdasarkan indikator kecerdasan emosional siswa yaitu mengenali dirinya sendiri bersikap tidak pasrah, mampu mengelola dan mengendalikan emosi, selalu optimis, mampu mengenali emosi orang lain (berempati) dan mampu membina kerja sama yang baik dengan orang lain (Lestari \& Yudhanegara, 2017). Berdasarkan hasil wawancara yang dilakukan oleh peneliti didapatlah informasi bahwa kebanyakan siswa cenderung malas untuk belajar dan mengerjakan soal dalam mata pelajaran matematika. Hal itu menunjukkan bahwa kecerdasan emosional siswa kelas XI di SMA Negeri 4 Kayuagung masih terbilang rendah. Dengan demikian pembelajaran harus dirancang sedemikian rupa sehingga dapat menumbuhkembangkan kemampuan berpikir kritis dan kecerdasan emosional siswa.

Salah satu pendekatan pembelajaran yang dapat diterapkan dalam pembelajaran matematika untuk meningkatkan kemampuan berpikir kritis dan kecerdasan emosional siswa adalah dengan menggunakan Pendekatan Metaphorical Thinking. Metaphorical Thinking adalah pendekatan pembelajaran yang lebih mengedepankan kepada aktivitas siswa berpikir secara metaforis dalam menemukan suatu ide untuk mengaitkan permasalahan pada soal dengan pengalaman sehari-hari (Setiawan, 2016). Menurut Holyoak \& Thagard, metafora bergerak dari suatu konsep yang diketahui siswa menuju konsep lain yang belum diketahui atau sedang dipelajari siswa (Afrilianto, 2014)

Tahapan-tahapan yang akan digunakan dalam penelitian ini adalah: Tahap 1: Memberikan masalah kontekstual dimana guru memberikan masalah kontekstual kepada siswa kemudian memberikan contoh metafora dalam kehidupan sehari-hari sebagai dasar agar siswa dapat memahami ide matematika yang akan disampaikan. Tahap 2: Memilih dan menggunakan metafora dimana guru memberikan kebebasan kepada siswa untuk memilih 
sebuah metafora yang akan digunakan. Tahap 3: Diskusi kelompok setekah guru memberikan kesempatan kepada siswa untuk bekerja dalam kelompok. Kelompok ini sebagai wadah diskusi siswa untuk saling bertukar metafora kepada teman sekelompoknya dan membandingkan metafora mana yang akan digunakan. Tahap 4: Memberikan kesimpulan dari hasil yang telah diperoleh masing-masing kelompok dipresentasikan di depan kelas dan nantinya akan ditanggapi oleh kelompok lainnya. Guru hanya memberikan arahan dan tambahan.

\section{METODE PENELITIAN}

Penelitian ini dilaksanakan di SMA Negeri 4 Kayuagung yang beralamat di Jalan Lintas Timur, Kelurahan Tanjung Rancing, Kecamatan Kota Kayuagung Kabupaten Ogan Komering Ilir (OKI), Sumatera Selatan. dengan materi yang diteliti adalah program linear di kelas XI MIPA. Pengambilan data pada penelitian ini dilaksanakan pada semester ganjil tahun peajaran 2018/2019 yang terhitung mulai dari tanggal 23 Juli sampai 3 Agustus 2018. Populasi dalam penelitian ini adalah seluruh siswa Kelas XI SMA Negeri 4 Kayuagung Tahun pelajaran 2018/2019. Pengambilan sampel menggunakan teknik simple random sampling. Teknik simple random sampling dilakukan dengan cara memilih sampel secara acak dari keseluruhan kelas XI di SMA Negeri 4 Kayuagung, dimana satu kelas sebagai kelas eksperimen dan satu kelas lainnya sebagai kelas kontrol.

Dalam penelitian ini merupakan penemitian kuantitatif dengan metode yang akan digunakan adalah metode True Experimental Design (Posttest-Only Control Design) yang mana dalam desain ini peneliti dapat mengontrol semua variabel luar yang mempengaruhi jalannya eksperimen (Sugiyono, 2013). Bentuk desain metode eksperimen yang digunakan yaitu Posttest-Only Control Design (Arikunto, 2013). Penelitian ini dilakukan dengan empat kali pertemuan pada kelas eksperimen dan kelas kontrol. Tiga kali pertemuan dilakukan pembelajaran, dan pada pertemuan keempat dilakukan tes akhir (Post-test).

Tes akhir berupa pemberian 5 soal uraian untuk mengukur kemampuan berpikir kritis siswa, dengan skala skor 0-4 untuk setiap idikatornya. Nilai persentase kemampuan berpikir kritis yang diperoleh dari perhitungan kemudian dikategorikan sesuai dengan Tabel 1 berikut ini: 
Tabel 1. Kategori Persentase Kemampuan Berpikir Kritis

\begin{tabular}{cc}
\hline Interpretasi $\mathbf{( \% )}$ & Kategori \\
\hline $81,25<\mathrm{X} \leq 100$ & Sangat Tinggi \\
$71,5<\mathrm{X} \leq 81,25$ & Tinggi \\
$62,5<\mathrm{X} \leq 71,5$ & Sedang \\
$43,75<\mathrm{X} \leq 62,5$ & Rendah \\
$0<\mathrm{X} \leq 43,75$ & Sangat Rendah \\
\hline
\end{tabular}

Sumber: (Karim \& Normaya, 2015)

Dalam penelitian ini juga diberikan tes akhir berupa angket. Angket yang digunakan adalah bentuk angket tertutup atau kuesioner yang berupa pilihan. Angket ini digunakan untuk mengetahui skala kecerdasan emosional siswa dengan jumlah 25 butir pernyataan. Skala yang digunakan dalam angket ini adalah skala Likert, yang terdiri dari empat pilihan yaitu: Sangat Setuju (SS), Setuju (S), Tidak Setuju (TS), dan Sangat Tidak Setuju (STS). Adapun skor dari pernyataan positif dan negatif pada angket tercantum pada Tabel 2 di bawah ini:

Tabel 2. Kategori Jawaban Angket Kecerdasan Emosional

\begin{tabular}{ccc}
\hline \multirow{2}{*}{ Alternatif Jawaban } & \multicolumn{2}{c}{ Skor untuk pernyataan } \\
\cline { 2 - 3 } & Positif & Negatif \\
\hline Sangat Setuju (SS) & 4 & 1 \\
Setuju (S) & 3 & 2 \\
Tidak Setuju (TS) & 2 & 3 \\
Sangat Tidak Setuju (STS) & 1 & 4 \\
\hline
\end{tabular}

Skor pada angket kecerdasan emosional akan dikualifikasikan sesuai dengan skor yang diperoleh yang akan dikategorikan dengan Tabel 3 berikut ini:

Tabel 3. Kualifikasi Hasil Skor Angket Kecerdasan Emosional

\begin{tabular}{cc}
\hline Skor Angket & Kategori \\
\hline $91-100$ & Amat Baik \\
$81-90$ & Baik \\
$71-80$ & Cukup \\
$60-70$ & Sedang \\
$\leq 60$ & Kurang \\
\hline
\end{tabular}


Selanjutnya, data dianalisis menggunakan uji independent sample t-test. Uji independent sample t-test atau uji-t dua variabel bebas adalah untuk membandingkan apakah kedua variabel tersebut sama atau berbeda (Hamzah, 2014). Dengan kriteria Uji-t terima $H_{0}$ jika signifikan (2-tailed) $>0,025$ dan tolak $H_{0}$ jika signifikan (2-tailed) $\leq 0,025$ (Kesumawati \& Aridanu, 2017). Uji normalitas yang digunakan dalam penelitian ini yaitu uji Kolmogorov-Smirnov dengan menggunakan bantuan program komputer SPSS (Statistical Product and Service Solution) versi 22 for Windows. Kriteria pengujian dengan menggunakan Kolmogorov-Smirnov yakni data dikatakan berdistribusi normal apabila (Kadir, 2015). Jika nilai (Signifikan) $>\alpha(0,05)$ maka sampel berasal dari populasi yang berdistribusi normal dan jika nilai (Signifikan) $\leq \alpha(0,05)$ maka sampel berasal dari populasi yang berdistribusi tidak normal.

Uji homogenitas dalam penelitian ini menggunakan uji Levene dengan menggunakan bantuan program komputer SPSS (Statistical Product and Service Solution) versi 22 for Windows. Uji homogenitas varians dengan menerapkan statistik levene's test of homogeneity of variances dikatakan memenuhi asumsi bahwa variansnya homogen dengan ketentuan sebagai berikut (Kesumawati \& Aridanu, 2017). Jika nilai signifikan > $\alpha(0,05)$ maka varians sampel dinyatakan homogen dan jika nilai signifikan $\leq \alpha(0,05)$ maka varians sampel dinyatakan tidak homogen.

Dalam penelitian ini, pembelajaran menggunakan Pendekatan Metaphorical Thinking dapat dikatakan berpengaruh pada kemampuan berpikir kritis dan kecerdasan emosional siswa jika pada saat dilakukan pengujian Uji-t menggunakan SPSS (Statistical Product and Service Solution) versi 22 for Windows didapat nilai signifikan (2-tailed) $\leq$ 0,025 .

\section{HASIL DAN PEMBAHASAN}

Data yang diperoleh dalam penelitian ini terdiri atas skor kemampuan berpikir kritis dan skor kecerdasan emosional siswa SMA Negeri 4 Kayuagung. Berikut disajikan deskripsi data kemampuan berpikir kritis pada Tabel 4 dibawah ini: 
Tabel 4. Data Setiap Indikator Kemampuan Berpikir Kritis

\begin{tabular}{cccc}
\hline \multirow{2}{*}{ No } & $\begin{array}{c}\text { Indikator Kemampuan } \\
\text { Berpikir Kritis }\end{array}$ & Kelas Eksperimen & Kelas Kontol \\
\cline { 3 - 4 } & Interpretasi & Rata-rata & Rata-rata \\
\hline 1 & Analisis & 91,8 & 84,8 \\
2 & Evaluasi & 91,8 & 80,6 \\
3 & Inferensi & 75,5 & 58,3 \\
4 & & 57,2 & 35,7 \\
\hline
\end{tabular}

Dari hasil tes kemampuan berpikir kritis siswa di kelas eksperimen dan kelas kontrol, peneliti mencari nilai rata-rata secara keseluruhan. Adapun nilai rata-rata hasil tes akhir (posttest) siswa pada kelas eksperimen dan kelas kontrol dapat dilihat pada Tabel 5 di bawah ini:

Tabel 5. Hasil Tes Kemampuan Berpikir Kritis Siswa

\begin{tabular}{ccc}
\hline \multirow{2}{*}{ Statistik } & \multicolumn{2}{c}{ Pembelajaran } \\
\cline { 2 - 3 } & Pendekatan Metaphorical Thinking & Konvensional \\
\hline$n$ & 30 & 33 \\
Rata - rata & 79,08 & 64,89 \\
Kategori & Tinggi & Sedang \\
\hline
\end{tabular}

Dari tabel di atas menunjukkan bahwa nilai rata-rata hasil tes akhir berpikir kritis pada kelas eksperimen yang diberi perlakuan dengan Pendekatan Metaphorical Thinking dikategorikan tinggi dengan nilai sebesar rata-rata 79,08 dan kelas kontrol yang diberi perlakuan dengan pembelajaran konvensional kemampuan berikir kritisnya dikategorikan sedang dengan nilai rata-rata 64,89. Pembahasan deskrpsi data kecerdasan emosional disajikan pada Tabel 6 berikut:

Tabel 6. Data Setiap Indikator Kecerdasan Emosional

\begin{tabular}{clcc}
\hline \multirow{2}{*}{ No } & \multirow{2}{*}{$\begin{array}{c}\text { Indikator Kemampuan } \\
\text { Berpikir Kritis }\end{array}$} & Kelas Eksperimen & Kelas Kontrol \\
\cline { 3 - 4 } & & Rata-rata & Rata-rata \\
\hline 1 & Mengenali Emosi & 80,83 & 78,96 \\
2 & Mengelola Emosi & 80,14 & 77,36 \\
3 & Memotivasi Diri & 88,33 & 76,46 \\
4 & Mengenali Emosi Orang Lain & 81,67 & 79,83 \\
5 & Membangun Hubungan & 82,08 & 78,47 \\
\hline
\end{tabular}


Dari hasil tes angket kecerdasan emosional siswa di kelas eksperimen dan kelas kontrol, peneliti mencari nilai rata-rata secara keseluruhan. Adapun nilai rata-rata hasil tes angket siswa pada kelas eksperimen dan kelas kontrol dapat dilihat pada Tabel 7:

Tabel 7. Hasil Tes Kecerdasan Emosional Siswa

\begin{tabular}{ccc}
\hline \multirow{2}{*}{ Statistik } & \multicolumn{2}{c}{ Pembelajaran } \\
\cline { 2 - 3 } & Pendekatan Metaphorical Thinking & Konvensional \\
\hline$n$ & 30 & 33 \\
Rata - rata & 82,33 & 71,12 \\
Kategori & Baik & Cukup \\
\hline
\end{tabular}

Dari tabel di atas menunjukkan bahwa nilai rata-rata hasil tes akhir kecerdasan emosional siswa pada kelas eksperimen yang diberi perlakuan dengan Pendekatan Metaphorical Thinking dikategorikan baik dengan nilai rata-rata 82,33 dan kelas kontrol yang diberi perlakuan dengan pembelajaran konvensional kecerdasan emosionalnya cukup dengan nilai rata-rata 71,12 . Untuk mengetahui ada atau tidaknya pengaruh pembelajaran Pendekatan Metaphorical Thinking terhadap kemampuan berpikir kritis dan kecerdasan emosional siswa, terlebih dahulu dilakukan uji normalitas data. Berikut disajikan hasil uji normalitas data menggunakan SPSS (Statistical Product and Service Solution) versi 22 for Windows pada Tabel 8 dibawah ini:

Tabel 8. Hasil Hitung Uji Normalitas Data

\begin{tabular}{ccc|ccc}
\hline \multicolumn{2}{c}{ Kemampuan Berpikir Kritis } & \multicolumn{3}{c}{ Kecerdasan Emosional } \\
\hline Pembelajaran & Sig & Kesimpulan & Kelas & Sig & Kesimpulan \\
\hline $\begin{array}{c}\text { Eksperimen } \\
\text { Kontrol }\end{array}$ & 0,200 & $\begin{array}{c}\text { Data Berdistribusi } \\
\text { Normal }\end{array}$ & $\begin{array}{c}\text { Eksperimen } \\
\text { Kontrol }\end{array}$ & 0,200 & $\begin{array}{c}\text { Data Berdistribusi } \\
\text { Normal }\end{array}$ \\
\hline
\end{tabular}

Selain data harus berdistribusi normal, data juga harus berasal dari populasi yang homogen. Hasil perhitungan uji homogenitas data dapat dilihat pada Tabel 9 dibawah ini:

Tabel 9. Hasil Hitung Uji Homogenitas Data

\begin{tabular}{ccc|ccc}
\hline \multicolumn{2}{c|}{ Kemampuan Berpikir Kritis } & \multicolumn{3}{c}{ Kecerdasan Emosional } \\
\hline Pembelajaran & Sig & Kesimpulan & Kelas & Sig & Kesimpulan \\
\hline $\begin{array}{c}\text { Eksperimen } \\
\text { Kontrol }\end{array}$ & 0,752 & $\begin{array}{c}\text { Data Berdistribusi } \\
\text { Normal }\end{array}$ & $\begin{array}{c}\text { Eksperimen } \\
\text { Kontrol }\end{array}$ & 0,054 & $\begin{array}{c}\text { Data Berdistribusi } \\
\text { Normal }\end{array}$ \\
\hline
\end{tabular}


Setelah data dinyatakan berdistribusi normal dan homogen, maka pengujian dapat dilanjutkan dengan Uji-t Independent Sampe t-Test. Hasil perhitungan data uji t menggunakan program SPSS 22 For Windows dapat dilihat pada Tabel 10 di bawah ini:

\section{Tabel 10. Hasil Hitung Uji Hipotesis}

\begin{tabular}{cccccc}
\hline \multicolumn{3}{c}{ Kemampuan Berpikir Kritis } & \multicolumn{3}{c}{ Kecerdasan Emosional } \\
\hline Sig & $H_{0}$ & Kesimpulan & Sig & $H_{0}$ & Kesimpulan \\
\hline 0,001 & Ditolak & Ada Pengaruh & 0,001 & Ditolak & Ada Pengaruh \\
\hline
\end{tabular}

Berdasarkan hasil perhitungan pada tabel 10 di atas, tes kemampuan berpikir kritis siswa diperoleh hasil nilai signifikan $(\rho)=0,001$ karena $\rho=0,001(\rho \leq 0,025)$ maka dapat disimpulkan bahwa terdapat pengaruh Pendekatan Metaphorical Thinking terhadap kemampuan berpikir kritis siswa kelas XI SMA Negeri 4 Kayuagung. Sedangkan untuk angket kecerdasan emosional siswa diperoleh hasil nilai signifikan $(\rho)=0,001$ karena $\rho=$ $0,001(\rho \leq 0,025)$ maka dapat disimpulkan bahwa terdapat pengaruh Pendekatan Metaphorical Thinking terhadap kecerdasan emosional siswa kelas XI SMA Negeri 4 Kayuagung.

Secara rinci, dapat diketahui bahwa rata-rata skor kemampuan berpikir kritis dan kecerdasan emosional siswa SMA Negeri 4 Kayuagung yang mengikuti pembelajaran dengan Pendekatan Metaphorical Thinking lebih baik dibandingkan siswa yang yang mengikuti pembelajaran secara konvensional. Temuan ini menunjukkan kuatnya pengaruh pembelajaran dengan Pendekatan Metaphorical Thinking terhadap kemmapuan berpikir kritis dan kecerasan emosional siswa. 


\section{KESIMPULAN}

Berdasarkan data hasil penelitian, pengelolaan data, analisis statistik hasil penelitian dan pembahasan, dapat disimpulkan bahwa Terdapat pengaruh Pendekatan Metaphorical Thinking terhadap Kemampuan Berpikir Kritis siswa SMA Negeri 4 Kayuagung. Hal ini dapat dilihat dari nilai rata-rata tes akhir siswa yang diberi perlakuan dengan Pendekatan Metaphorical Thinking yaitu 79,08 lebih tinggi dibandingkan siswa yang diberi perlakuan dengan pembelajaran konvensional yaitu 64,89. Dan terdapat pengaruh Pendekatan Metaphorical Thinking terhadap Kemampuan Berpikir Kritis siswa SMA Negeri 4 Kayuagung. Hal ini dapat dilihat dari nilai rata-rata tes angket siswa yang diberi perlakuan dengan Pendekatan Metaphorical Thinking yaitu 82,33 lebih tinggi dibandingkan siswa yang diberi perlakuan dengan pembelajaran konvensional yaitu 71,12. Setelah melakukan penelitian kemampuan berpikir kritis siswa dan kecerdasan emosional siswa menggunakan Pendekatan Metaphorical Thinking di SMA Negeri 4 Kayuagung, beberapa saran yang dapat peneliti berikan antara lain: sebagai bahan informasi dan bahan masukan dalam menentukan model pembelajaran yang bervariasi dengan tujuan untuk meningkatkan kemampuan berpikir kritis dan kecerdasan emosional siswa. Bagi peneliti selanjutnya, dalam melaksanakan pembelajaran dengan menggunakan Pendekatan Metaphorical Thinking hendaknya dapat memaksimalkan pengelolaan kelas agar alokasi waktu yang terbatas tidak menjadi kendala. Peneliti selanjutnya dapat menghemat waktu pembelajaran dengan menyusun LKS yang lebih sempurna sehingga tujuan pembelajaran yang diharapkan dapat tercapai sesuai dengan waktu yang telah ditetapkan. 


\section{DAFTAR PUSTAKA}

Adeyanto, R., Kusmayadi, T. A., \& Riyadi. (2016). Eksperimentasi Model Pembelajaran Kooperatif Missouri Mathematics Project (MMP) Dan Think Pair Share (TPS) dengan pendekatan Saintifik Pada Maetri Persamaan Garis Lurus Ditinjau dari Kecerdasan Emosional Siswa SMP Negeri Se-Kabupaten Pemalang Tahun Pelaja. Journal of Mathematics and Mathematics Education, 6(1), 25-33.

Afrilianto, M. (2014). Pendekatan Metaphorical Thinking Untuk Meningkatkan Kemampuan Kompetensi Strategis Matematis Siswa SMP. Prosiding Seminar Nasional Matematika Dan Pendidikan Matematika, 68.

Arikunto, S. (2013). Prosedur Penelitian: Suatu Pendekatan Praktik (Edisi Revisi). In Jakarta: Rineka Cipta. https://doi.org/10.1017/CBO9781107415324.004

Asnawati, S., K.D., I. L., \& Muhtarulloh, F. (2015). PENERAPAN PEMBELAJARAN INKUIRI DENGAN ETNOMATEMATIK PADA MATERI BIDANG DATAR TERHADAP KEMAMPUAN PEMAHAMAN MATEMATIS SISWA. Euclid, 2 (2), 275-295. https://doi.org/10.33603/e.v2i2.363

Aunurrahman. (2016). Belajar dan Pembelajaran. Bandung: Alfabeta.

Hamalik, O. (2017). Kurikulum dan Pembelajaran. Jakarta: Bumi Aksara.

Hamzah, A. (2014). Evaluasi Pembelajaran Matematika. Jakarta: Rajawali Press.

Kadir. (2015). Statistika Terapan. Jakarta: PT Raja Garafindo Persada.

Karim, K., \& Normaya, N. (2015). Kemampuan Berpikir Kritis Siswa dalam Pembelajaran dalam Pembelajaran Matematika dengan Menggunakan Model Jucama di Sekolah Menengah Pertama. EDU-MAT: Jurnal Pendidikan Matematika, 3(1), 95. https://doi.org/10.20527/edumat.v3i1.634

Kesumawati, N., \& Aridanu, I. (2017). Statistik Parametrik Penelitian Pendidikan Matematika. Palembang: Noerfikri.

Lestari, K. E., \& Yudhanegara, M. R. (2017). Penelitian Pendidikan Matematika. Karawang: Refika Aditama.

Puspendik. (2017). Mengenai TIMSS. Retrieved from Pusat Penilaian Pendidikan Badan Penelitian dan Pengembangan website: puspendik.kemendikbud.go.id

Setiawan, W. (2016). Profil Berpikir Metaforis (Metaphorical Thinking) Siswa SMP dalam Memecahkan Masalah Pengukuran Ditinjau dari Gaya Kognitif. Kreano, Jurnal Matematika Kreatif-Inovatif, 7(2), 208-216. https://doi.org/10.15294/ kreano.v7i2.7127

Sugiyono. (2013). Metode Penelitian Pendidikan Pendekatan Kuantitaif, Kualitatif, dan R\&D. Metode Penelitian Pendidikan Pendekatan Kuantitaif, Kualitatif, Dan R\&D, pp. 283-393. https://doi.org/10.1007/s13398-014-0173-7.2 
Susanto, A. (2016). Teori Belajar dan Pembelajaran di Sekolah Dasar. Jakarta: Prenada Media Group. 